\title{
Tips dan Trik Menghadapi Soal-Soal Bahasa Inggris Ujian Nasional SMA/SMK
}

Budiati1 $^{1}$ Tri Arie Bowo ${ }^{2}$

${ }^{1}$ Program Studi Sastra Inggris, Fakultas Hukum dan Humaniora, Universitas Ngudi Waluyo, Gedung M, Lantai 2, Jl, Diponegoro No 186 Gedanganak, Kabupaten Semarang, Provinsi Jawa Tengah, Indonesia 50512

2Program Studi Sastra Inggris, Fakultas Ilmu Sosial dan Ilmu Politik, Universitas Bangka Belitung, Gedung Babel I, Lantai 2, Merawang, Kabupaten Bangka, Provinsi Kepulauan Bangka Belitung - 33172

*Penulis koresponden: arie622@gmail.com

\begin{tabular}{l}
\hline Info Artikel \\
\hline Riwayat : \\
Dikirim 16 September 2021 \\
Direvisi 30 Desember 2021 \\
Diterima 31 Desember 2021
\end{tabular}

\section{Kata Kunci :}

Tips dan Trik

Soal Bahasa Inggris

Ujian Nasional

\begin{abstract}
Abstrak
Program Pengabdian kepada Masyarakat Tips and Trik Menghadapi Soal-Soal Bahasa Inggris Ujian Nasional SMA/SMK bertujuan untuk mempersiapkan siswa-siswa kelas XII SMA/SMK di SMA dan SMK Islam Sudirman Kedungjati, Grobogan dalam menghadapi soal-soal Bahasa Inggris UN 2018. Metode yang digunakan yakni simulasi dan pembahasan soal-soal Bahasa Inggris beserta tips dan trik untuk menyelesaikan soal-soal tersebut. Program Pengabdian kepada Masyarakat ini dilakukan di SMA Islam Sudirman dan SMK Islam Sudirman Kedungjati, Grobogan, Jawa Tengah dalam jangka waktu satu bulan. Dari hasil kegiatan ini didapatkan perubahan yang signifikan sebelum dan sesudah dilakukan treatment. Hal ini dilihat dari perbandingan nilai rata-rata pre-test dan post-test. Di SMK Islam Sudirman diperoleh nilai rata-rata pre-test adalah 30,64 , sementara pada nilai post-test diperoleh 40.39, sehingga terjadi kenaikan 9.76 atau 38.99\%. Di SMA Islam Sudirman diperoleh nilai rata-rata pretest adalah 26.73 dan pada post-test diperoleh nilai rata-rata 30.06 dengan kenaikan 3.33 atau 14.03\%. Diharapkan dari program ini adalah siswa-siswa SMK dan SMA Islam Sudirman dapat mempersiapkan Ujian Nasional secara lebih baik dan lebih dini.
\end{abstract}

\section{PENDAHULUAN}

Istilah UN (Ujian Nasional) sangatlah akrab bagi para pelajar SMP dan SMA/SMK. Keberadaan UN itu sendiri hingga sekarang masih sangat kontroversial diantara para guru karena dianggap tidak efektif dan tidak adil untuk penentuan kelulusan. UN dibuat oleh Departemen Pendidikan tanpa memperhatikan subjek dan kebutuhan siswa. Alangkah baiknya jika penilaian ditentukan dan diselenggarakan oleh masing-masing sekolah dimana gurulah yang mengetahui kompetensi siswa. Dalam penelitian yang dilakukan Alawiyah (2015), Baedowi, (2015:121) menyatakan UN telah mematikan kreativitas mengajar, karena pada akhirnya negara yang harus menentukan kewenangan kelulusan siswa. Dia juga menyampaikan bahwa UN dinilai telah menyampingkan keberadaan bakat dan kecerdasan yang dimiliki oleh setiap peserta didik.

Namun begitu, pemerintah masih menyelenggarakan UN yang danggap sebagai standar kelulusan yang bisa diterima. Lomax (1991) dalam Hidayah (2013) menyampaikan ada 3 dampak negative dengan adanya ujian yang terstandarisasi dan tersentralisasi, yaitu berkurangnya waktu untuk pengajaran, diabaikannya materi kurikulum yang tidak diujikan, dan meningkatnya pemakaian materi persiapan yang mirip dengan tes.

Standar kelulusan UN dari tahun ke tahun pun semakin tinggi tanpa mempertimbangkan kondisi lokasi dan siswa sehingga menjadikan UN sebagai hal yang menakutkan baik bagi guru maupun 
siswa sendiri. Hal ini bisa dilihat dalam perubahan standar nilai seperti yang dituliskan Hidayah (2013) dalam penelitiannya sebagai berikut:

- Ujian Nasional tahun 2005 minimal nilai untuk setiap mata pelajaran adalah 4.25.

- Ujian Nasional tahun 2006 standar kelulusan minimal adalah 4.25 untuk tiap mata pelajaran yang diujikan dan rata-rata nilai harus lebih dari 4.50 dan tidak ada ujian ulang.

- Ujian Nasional tahun 2007 nilai rata-rata minimal 5.00 untuk seluruh mata pelajaran dengan tidak ada nilai dibawah 4.25 ; jika nilai minimal 4.00 pada salah satu mata pelajaran yang diujikan maka nilai pada dua mata pelajaran lainnya adalah 6.00

- Ujian Nasional 2008 nilai rata-rata minimal 5.25.

- Ujian Nasional 2009 standar kelulusan minimal 5.50 untuk seluruh mata pelajaran yang di-UNkan dengan nilai minimal 4.00 untuk paling banyak 2 mata pelajaran dan minimal 4.25 untuk mata pelajarn lainnya.

- Ujian Nasional 2010 standar kelulusan minimal 5.50 untuk seluruh mata pelajaran yang diujikan dengan nilai minimal 4.00 untuk paling banyak dua mata pelajaran dan minimal 4.25 untuk mata pelajaran lainnya. Khusus untuk SMK, nilai mata pelajaran praktek kejuruan minimal 7.00

Tingkat kesulitan ini juga sangat dirasakan untuk mata pelajaran Bahasa Inggris. Standar Kelulusan bagi siswa SMA/SMK untuk Bahasa Inggris juga tinggi dimana kompetensi Bahasa Inggris diwakili dalam bentuk tes listening dan Reading dan structure. Adapun SKL siswa SMA/ SMK dapat ditunjukkan pada Tabel 1 sebagai berikut. (https://www.kemdikbud.go.id)

Tabel 1 Kisi-Kisi Ujian Nasional Sekolah Menengah Kejuruan/Madrasah Aliyah Kejuruan Tahun Pelajaran 2017/2018

Level Kognitif Lingkup Materi

\begin{tabular}{|c|c|c|c|}
\hline & Fungsi Sosial & Struktur Teks & Unsur Kebahasaan \\
\hline $\begin{array}{l}\text { Pengetahuan dan } \\
\text { Pemahaman } \\
\text { - Mengidentifikasi }\end{array}$ & $\begin{array}{l}\text { Peserta didik dapat } \\
\text { mengidentifikasi aspek- } \\
\text { aspek fungsi sosial: } \\
\text { - topik/isu/masalah } \\
\text { - tujuan/fungsi/pesa } \\
\text { n latar } \\
\text { - belakang/alasan } \\
\text { - akibat/dampak/ma } \\
\text { nfaat } \\
\text { - sikap/nilai yang } \\
\text { diusung } \\
\text { - peran dan fungsi } \\
\text { pembicara/penulis } \\
\text { - peran dan fungsi } \\
\text { pendengar/pembaca } \\
\text { - konteks }\end{array}$ & $\begin{array}{l}\text { Peserta didik dapat } \\
\text { mengidentifikasi keterkaitan } \\
\text { makna antar bagian-bagian } \\
\text { dalam teks: } \\
\text { - pandangan, maksud, } \\
\text { pendapat yang menjadi } \\
\text { ide utama c } \\
\text { - rincian argumentasi, } \\
\text { langkah- angkah, } \\
\text { peristiwa, deskripsi } \\
\text { - plot, alur pikiran }\end{array}$ & $\begin{array}{l}\text { Peserta didik dapat } \\
\text { mengidentifikasi unsur } \\
\text { kebahasaan yang terkait } \\
\text { dengan isi teks lisan dan } \\
\text { tertulis berikut ini: } \\
\text { - persamaan } \\
\text { makna frasa, makna } \\
\text { idiom } \\
\text { - word order } \\
\text { - article, demonstrative, } \\
\text { possessive pronoun } \\
\text { - agreement dan number } \\
\text { - tenses } \\
\text { - passive voice } \\
\text { - referensi gramatika } \\
\text { - kata sambung } \\
\text { - preposisi }\end{array}$ \\
\hline
\end{tabular}


Buletin Pembangunan Berkelanjutan

Vol. 5 No. 3, Desember 2021 hal. 28-39

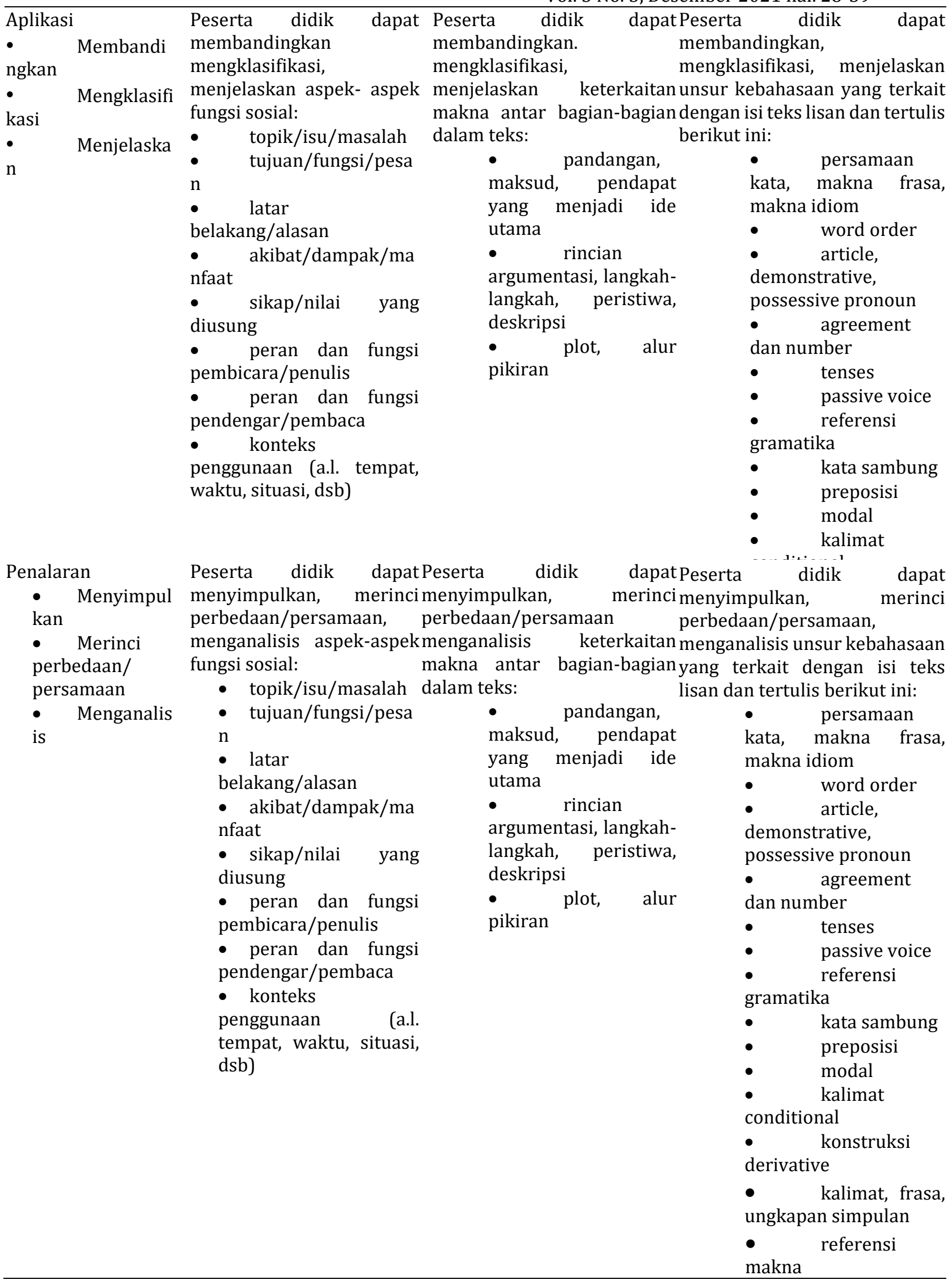


Keterangan :

Jenis teks-teks lisan dan tertulis untuk cakupan materi fungsi sosial dan struktur teks:

1. Interaksi transaksional/interpersonal tertulis (a.l. memuji, menawarkan, menyarankan)

2. Fungsional pendek (a.l. announcement, notice, label)

3. Descriptive, recount, procedure, report

Sedangkan untuk yang SMA/MA dapat dilihat pada Tabel 2 berikut ini.

Tabel 2 Kisi-Kisi Ujian Nasional Sekolah Menengah Atas/Madrasah Aliyah, Sekolah Menengah Teologi Kristen, dan Sekolah Menengah Agama Katolik Tahun Pelajaran 2017/2018

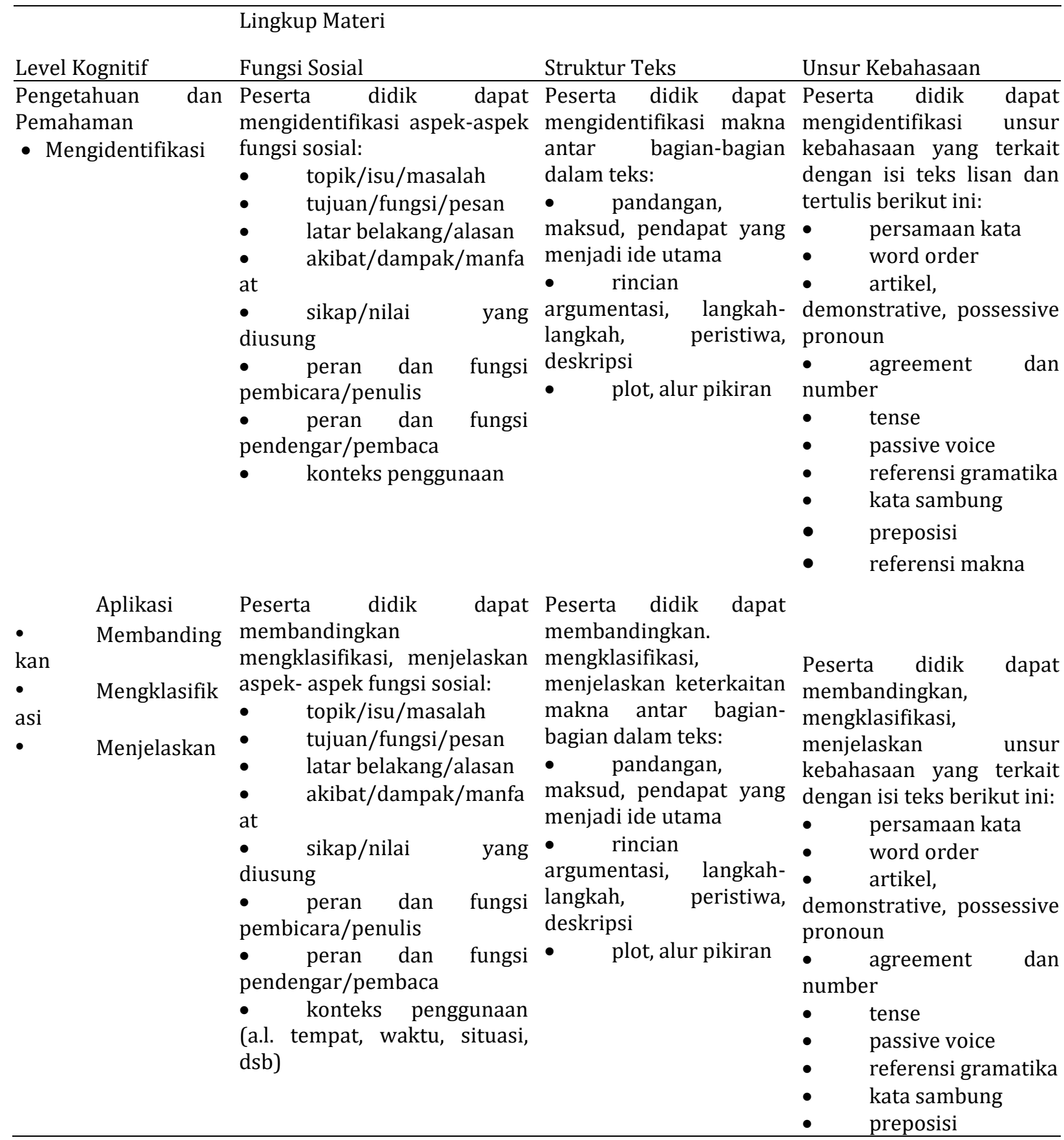




\begin{tabular}{|c|c|c|c|}
\hline \multirow{7}{*}{$\begin{array}{ll}\text { - } & \text { Penalaran } \\
\text { Menyimpulk } \\
\text { - } & \text { Merinci } \\
& \text { perbedaan/ } \\
\text { - } & \text { Mersamaan } \\
\text { Menganalisis }\end{array}$} & \multirow{7}{*}{$\begin{array}{l}\text { Peserta didik dapat } \\
\text { menyimpulkan, merinci } \\
\text { perbedaan/persamaan, } \\
\text { menganalisis aspek-aspek } \\
\text { fungsi sosial: } \\
\text { - } \quad \text { topik/isu/masalah } \\
\text { - } \quad \text { tujuan/fungsi/pesan } \\
\text { - } \quad \text { latar belakang/alasan } \\
\text { - } \quad \text { akibat/dampak/manfa } \\
\text { at } \quad \text { sikap/nilai } \\
\text { - yang } \\
\text { diusung } \\
\text { - } \quad \text { peran dan fungsi } \\
\text { pembicara/penulis } \\
\text { - } \quad \text { peran dan fungsi } \\
\text { pendengar/pembaca } \\
\text { - konteks penggunaan }\end{array}$} & \multirow{7}{*}{$\begin{array}{l}\text { Peserta didik dapat } \\
\text { menyimpulkan, merinci } \\
\text { perbedaan/persamaan } \\
\text { menganalisis keterkaitan } \\
\text { makna antar bagian- } \\
\text { bagian dalam teks: } \\
\text { - pandangan, } \\
\text { maksud, pendapat yang } \\
\text { menjadi ide utama } \\
\text { - rincian } \\
\text { argumentasi, langkah- } \\
\text { langkah, peristiwa, } \\
\text { deskripsi } \\
\text { - plot, alur pikiran }\end{array}$} & $\begin{array}{ll}\text { - } & \text { modal } \\
\text { - } & \text { kalimat conditional } \\
\text { - } & \text { konstruksi } \\
\text { derivative } \\
\text { - } \quad \text { referensi makna }\end{array}$ \\
\hline & & & \multirow{4}{*}{$\begin{array}{l}\text { Peserta didik dapat } \\
\text { menyimpulkan, merinci } \\
\text { perbedaan, persamaan, } \\
\text { menganalisis unsur } \\
\text { kebahasaan yang terkait } \\
\text { dengan isi teks berikut ini: } \\
\text { - } \quad \text { persamaan kata } \\
\text { - } \quad \text { word order } \\
\text { - } \quad \text { artikel, } \\
\text { demonstrative, possessive } \\
\text { pronoun } \\
\text { - } \quad \text { agreement } \\
\text { number dan } \\
\text { - } \quad \text { tense } \\
\text { - } \quad \text { passive voice } \\
\text { - } \quad \text { referensi gramatika } \\
\text { - } \quad \text { kata sambung } \\
\text { - } \quad \text { preposisi } \\
\text { - } \quad \text { modal } \\
\text { - } \quad \text { kalimat conditional } \\
\text { derivative }\end{array}$} \\
\hline & & & \\
\hline & & & \\
\hline & & & \\
\hline & & & 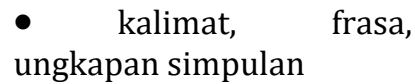 \\
\hline & & & - $\quad$ referensi makna \\
\hline
\end{tabular}

Keterangan : Jenis teks lisan dan tertulis untuk cakupan materi fungsi sosial dan struktur sosial

1) Interaksi transaksional/interpersonal tertulis (a.l. pendapat, pengandaian, memuji, mengkritik, jati diri)

2) Fungsional pendek (a.l. announcement, undangan, pemberitahuan)

3) Descriptive, recount, narrative, procedure, report, exposition, biography, news item

Ketakutan akan ketidaklulusan siswa, menjadikan guru melakukan berbagai upaya untuk menjadikan kelulusan siswa mencapai $100 \%$, salah satunya dengan pemberian pelajaran tambahan dan simulasi soal-soal UN. Drilling soal-soal UN pada siswa dilakukan untuk membuat siswa terbiasa dengan tipe soal dan mengenal soal dengan baik. Namun begitu, tidak semua sekolah mampu menyelenggarakan kegiatan tambahan ini dengan baik. Banyak kendala yang dihadapi salah satunya sarana dan prasarana yang terbatas. Kebijakan Ujian Nasional Berbasis Komputer seperti yang dituliskan dalam https://www.sudutbaca.com/kebijakan-ujian-nasional-tahun-2018/ mengenai hasil rapat koordinasi BNSP 2018 bahwa Ujian Nasinal di tingkat SMA 100\% menggunakan moda UNBK tentunya akan menambah permasalahan di sekolah-sekolah dengan keterbatasan sarana dan prasarana. UNBK yaitu Ujian Nasional Berbasis Komputer, menuntut fasilitas yang memadai untuk bisa diaplikasikan. Pengadaan hardware berupa computer itu sendiri maupun software berupa soal-soal ujian memerlukan dana yang cukup besar.

Permasalahan yang sama juga dirasakan oleh sekolah-sekolah yang berada di daerah. SMA dan SMK Islam Sudirman Kedungjati yang berlokasi di Desa Wonorejo, Kecamatan Kedungjati, Kabupaten Grobogan salah satunya. Sekolah-sekolah ini bukanlah sekolah yang berada di tengah kota dimana fasilitas internet dan wifi cukup untuk mengakses soal-soal online. Demikian juga kondisi sekolah yang memang bukan sekolah yang tergolong besar. Sebagai sekolah swasta dimana sumber pembiayaan 
Buletin Pembangunan Berkelanjutan

Vol. 5 No. 3, Desember 2021 hal. 28-39

utama adalah dari siswa (walaupun ada subsidi dari Yayasan) kemampuan untuk menyediakan sarana prasara yang memadai sangatlah terbatas. Simulasi UN diselenggarakan hanya menunggu dari kegiatan yang diselenggarakan oleh Dinas Pendidikan dan Kebudayaan Provinsi maupun Nasional. Sementara untuk kegiatan yang diselenggarakan secara mandiri sangat terbatas pada dana dan anggaran.

SMK Islam Sudirman Kedungjati mempunyai 3 jurusan yaitu Teknik Kendaraan Ringan, Busana Butik dan Teknik Audio Video, dengan jumlah siswa kelas XII sebanyak 66 orang. Sekolah ini terakreditasi C. Fasilitas dan sarana prasarana sekolah sangat minim (Gambar 1 dan Gambar 2).

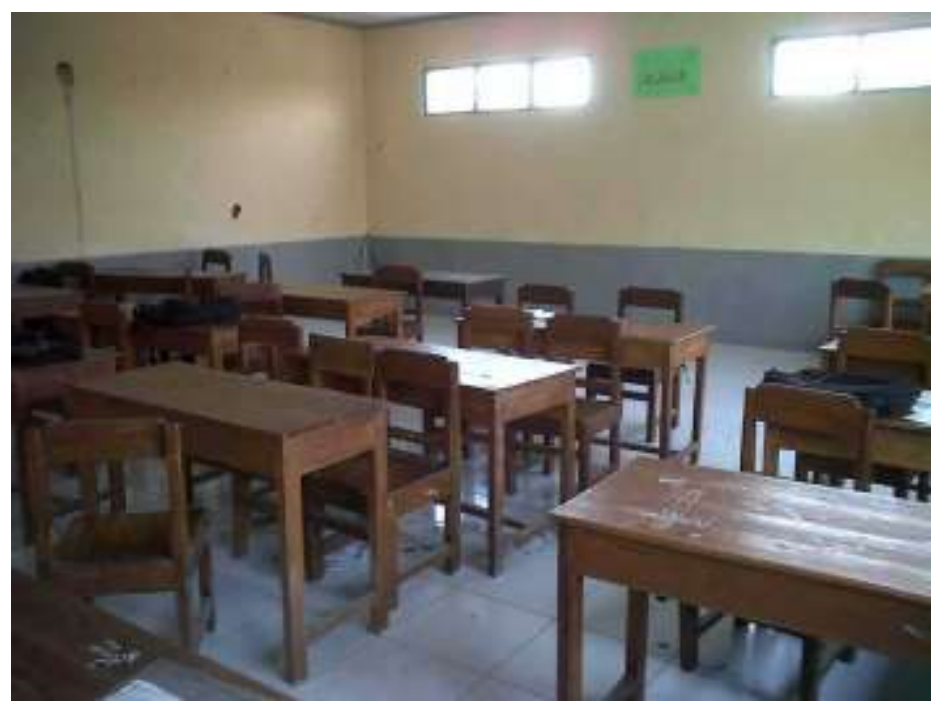

Gambar 1 Ruang Kelas

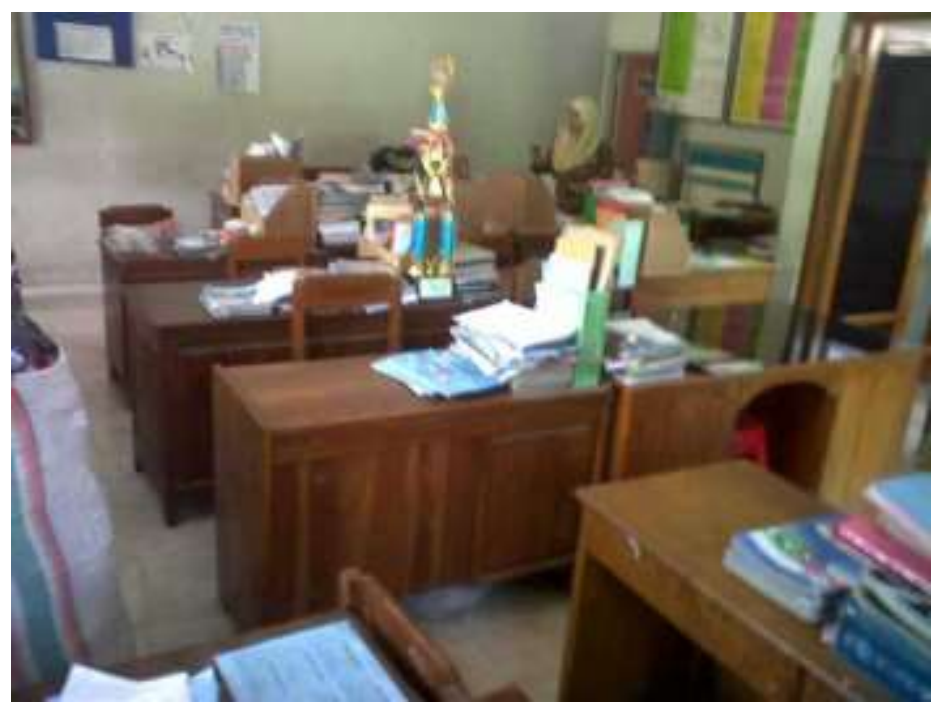

Gambar 2 Ruang Guru

Sementara itu, SMA Islam Sudirman Kedungjati kondisinya juga tidak jauh berbeda dari SMK Islam Sudirman Kedungjati. SMA ini terdiri dari 2 Jurusan yaitu IPA dan IPS dengan jumlah siswa kelas XII 60. Sarana dan prasarana sekolah masih sangat minim.

Melihat kondisi tersebut, tim Pengabdian kepada Masyarakat dari Program Studi Sastra Inggris Universitas Ngudi Waluyo menawarkan kegiatan simulasi soal Bahasa Inggris UN untuk SMA dan SMK beserta tip dan trik menyelesaikan soal-soal tersebut. Bahasa Inggris sebahai salah satu mata pelajaran yang di-UN-kan perlu mendapat perhatian karena pada mata pelajaran ini biasanya minat siswa sangat sedikit disbanding matematika maupun Bahasa Indonesia yang dianggap sebagai pelajaran sehari-hari.

SMK dan SMA Islam Sudirman Kedungjati adalah sekolah swasta dibawah yayasan Islamic Center (GUPPI) yang berlokasi di daerah yang cukup terpencil di desa Wonorejo, Kecamatan Kedungjati, Kabupaten Grobogan, Jawa Tengah. Kondisi masyarakat sekitar sebagian besar bermatapencaharian 
sebagai petani, buruh serabutan serta buruh di kota dengan tingkat perekonomian rendah. Angka pendidikan siswa yang melanjutkan ke perguruan tinggi masih sangat rendah. Hal ini disebabkan ekonomi masyarakat yang relatif rendah.

Hal tersebut juga mempengaruhi perkembangan sekolah untuk bisa memberikan fasilitas yang lebih bagi para siswa. Sebagai akibatnya beberapa kegiatan yang menggunakan dana besar tidak dapat diselenggarakan oleh sekolah. Persiapan UNBK dimana membutuhkan software dan hardware yang membutuhkan dana yang cukup besar tidak dapat diselenggarakan. Simulasi soal-soal UN hanya didapat dari kegiatan yang diselenggarakan oleh dinas terkait, sehingga persiapan untuk menghadapi UN sangat minim.

Untuk mengatasi permasalahan mitra kurangnya persiapan UN Bahasa Inggris, tim pelaksana Pengabdian Kepada Masyarakat Universitas Ngudi Waluyo memberikan solusi berupa pemberian tips dan trik penyelesaian soal-soal Bahasa Inggris Ujian Nasional SMA dan SMK. Kegiatan ini berupa bedah soal simulasi Ujian Nasional di SMA dan SMK berupa listening dan reading.

\section{METODE PELAKSANAAN}

Sasaran Pengabdian kepada masyarakat ini adalah siswa-siswa kelas XII SMA Islam Sudirman Kedungjati, Kabupaten Grobogan sebanyak 32 siswa dan siswa-siswa kelas XII SMK Islam Sudirman Kedungjati, Kabupaten Grobogan sebanyak 70 siswa. Metode pelaksanaan kegiatan ini adalah sebagai berikut:

1. Pre-test soal-soal Bahasa Inggris UN SMA dan SMK di sekolah.

2. Pembahasan soal dan pemberian tip dan trik mengerjakan soal dengan tipe-tipe soal tertentu.

3. Post-test untuk melihat progress yang didapat setelah diberikannya tip dan trik menyelesaikan soal listening, structure maupun reading.

Langkah-langkah kegiatan pengabdian kepada masyarakat kepada siswa-siswa kelas XII SMK Islam Sudirman dan SMA Islam Sudirman Kedungjati, Grobogan adalah sebagai berikut:

1. Pengenalan karakteristik dan kategori siswa melalui survey dan wawancara di sekolah

2. Penentuan materi soal-soal UN SMA dan SMK yang sesuai untuk sasaran kegiatan.

3. Pemilihan dan penyiapan materi. Dalam hal ini menentukan soal mana yang sesuai untuk siswa SMA dan yang sesuai untuk siswa SMK. meliputi:

Target sasaran yang berbeda memberikan penanganan yang berbeda pula. Penyiapan materi

1) Penyediaan buku referensi soal Bahasa Inggris UN SMA dan SMK

2) Penggandaan soal untuk masing-masing target sasaran

3) Penyiapan materi pembahasan soal

4) Penentuan kiat-kiat yang diberikan untuk siswa.

4. Pre-test untuk mengukur kemampuan awal siswa dalam mengerjakan soal-soal Bahasa Inggris UN. Pre-test ini meliputi soal listening dan reading yang di dalamnya juga terdapat soal structure dan grammar.

5. Pembahasan soal dan pemberian kiat-kiat mengerjakan soal, yang meliputi:

1) Mengenal jenis dan tipe soal

2) Strategi dan tip yang bisa digunakan untuk tiap jenis soal.

3) Memberikan contoh soal-soal yang hampir sama.

6. Post-test untuk mengetahui tingkat pemahaman siswa dan kemajuan setelah mendapatkan kiat-kiat mengerjakan soal-soal UN.

7. Penilaian dan pemeringkatan hasil pre-test dan post-test

Gambar 3 menunjukkan langkah-langkah kegiatan pelaksanaan Pengabdian. Bahan dan alat yang diperlukan adalah soal-soal bahasa Inggris UN SMA dan SMK. Soal Bahasa Inggris UN untuk SMA berbeda dengan soal Bahasa Inggris UN untuk SMK. Dimana soal untuk SMK lebih bersifat aplikatif dan lebih sederhana dibandingkan soal untuk SMA baik untuk soal listening maupun reading. Untuk mendapatkan soal yang berkualitas, soal-soal diambil dari buku Prediksi Soal-Soal UN SMA dan SMK yang diterbitkan oleh penerbit yang terpercaya. 


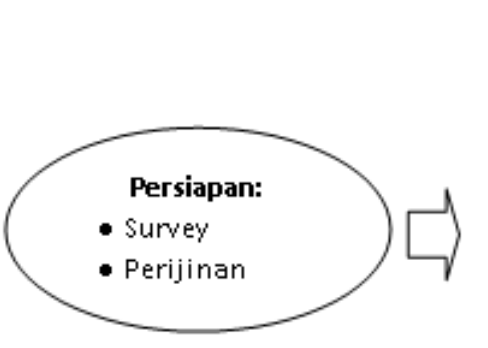

- Penyediaan buku referensi soal

- Penentuan soal

- Penggandaan soal

- Penyiapan materi pembahasan

- Penyiapantips dan trik pengerjaansoal

Vol. 5 No. 3, Desember 2021 hal. 28-39
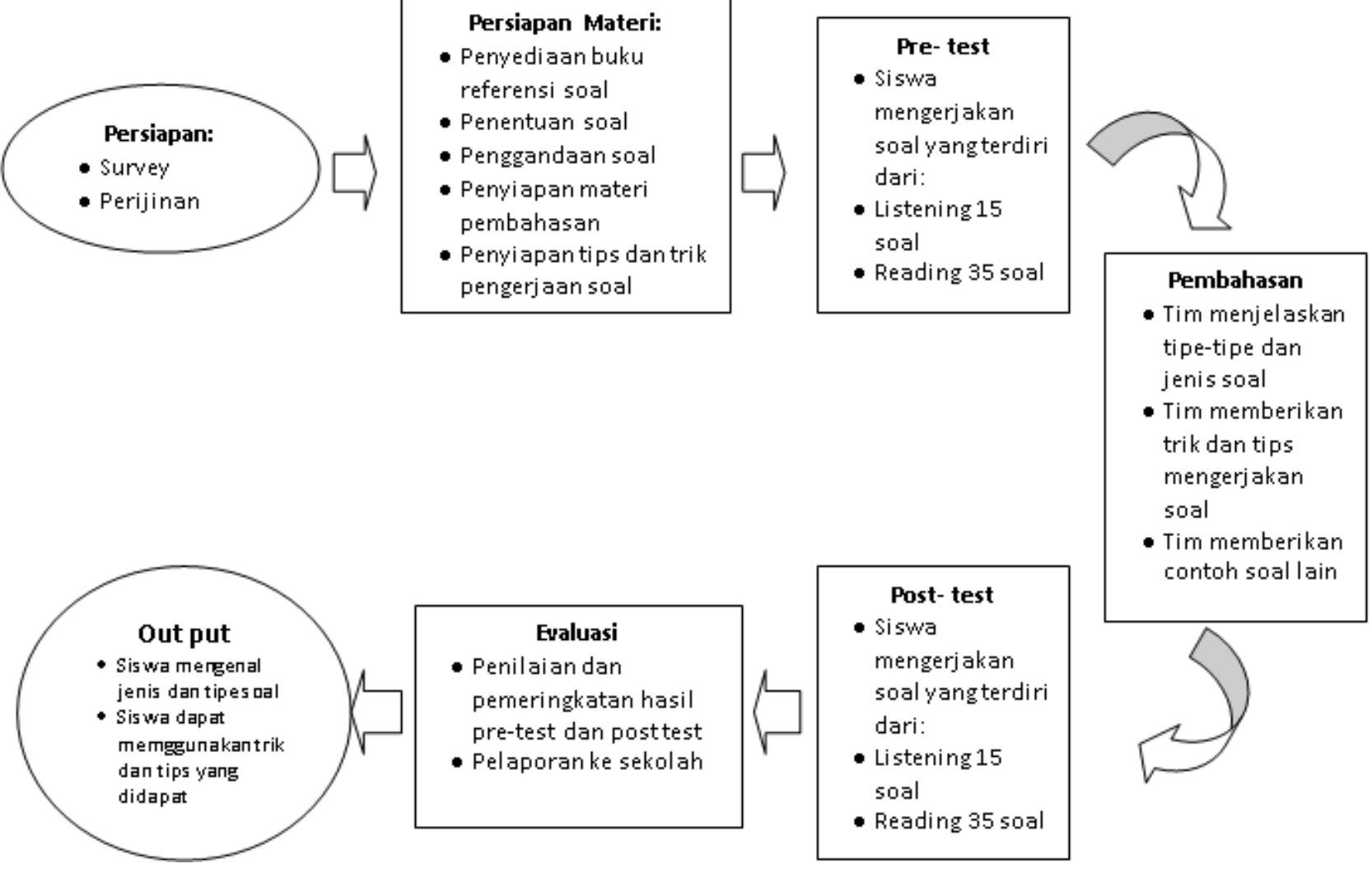

Gambar 3 Diagram Alir Pelaksanaan Kegiatan Pengabdian Masyarakat

Pada bagian metode penerapan, uraikanlah dengan jelas dan padat metode yang digunakan untuk mencapai tujuan yang telah dicanangkan dalam kegiatan pengabdian. Berisi lokasi dan partisipan kegiatan, bahan dan alat, metode pelaksanaan kegiatan, metode pengumpulan data, pengolahan, dan analisis data.

\section{HASIL DAN PEMBAHASAN}

Kegiatan persiapan ini diawali dengan survei untuk menentukan kelayakan tempat kegiatan pengabdian masyarakat. Hal ini dilakukan supaya sasaran dari program ini dapat tercapai sesuai target. Fokus dari kegiatan pengabdian ini selain untuk memberikan pengetahuan dan ilmu kepada mitra, juga diharapkan dapat mensosialisasikan Universitas Ngudi Waluyo. Akhirnya ditetapkan SMA Islam Sudirman Kedungjati dan SMK Islam Sudirman Kedungjati di Kabupaten Grobogan sebagai mitra kegiatan pengabdian masyarakat dengan pertimbangan:

1. Sekolah ini belum terjangkau informasi tentang Universitas Ngudi Waluyo. Masyarakat di desa ini tidak mengetahui adanya universitas di Ungaran ini, sehingga dirasa perlu memsosialisasikan universitas beserta program studi yang ditawarkan guna menjaring kerjasama mitra dan penerimaan mahasiswa baru.

2. Kondisi kedua sekolah dengan jumlah siswa yang cukup banyak tetapi sarana untuk persiapan Ujian Nasional sangat minim, sehingga dirasa perlu untuk mendapatkan program pengabdian masyarakat.

3. Kurangnya soal dan bahan simulasi soal-soal Bahasa Inggris UN. Dengan fasilitas yang minim di sekolah, persiapan UN dan simulasi dilakukan dengan mengikuti simulasi yang dilakukan oleh instansi terkait saja. Pengadaan secara mandiri sangat kurang.

Setelah dilakukan survei selanjutnya dilakukan pengajuan perijinan yang diawali dengan permohonan secara lisan atau informal ke masing-masing sekolah yang dilanjutkan permohonan ijin pelaksanaan pengabdian masyarakat secara resmi secara tertulis.

Tahap persiapan selanjutnya adalah penyiapan materi. Untuk penyiapan materi yang akan digunakan disesuaikan dengan target sasaran dimana untuk mitra 1 yang merupakan siaswa SMA berbeda dengan mitra 2 yang merupakan siswa SMK. Pada tahap ini dipilih soal-soal UN dari buku kumpulan soal-soal UN maupun prediksi soal-soal UN SMA dan SMK yang memang berkualitas yang 
disesuaikan dengan sasaran. Soal-soal UN untuk SMK bersifat lebih sederhana dan praktis dibanding dengan SMA.

Selanjutnya soal-soal yang telah ditentukan digandakan sesuai dengan kebutuhan dan dibuat sesuai dengan paket soal. Sementara itu juga telah disiapkan tips dan trik mengenal dan mengerjakan soal dengan mudah.

\section{Pre Test}

Pelaksanaan kegiatan pengabdian masyarakat di 2 mitra yaitu SMA dan SMK Islam Sudirman Kedungjati diawali dengan pre-test. Kegiatan ini dimungkinkan untuk mengetahui kemampuan awal dari para siswa sebelum mendapatkan treatment.

Pelaksanaan pre-test di SMK Islam Sudirman Kedungjati dilaksanakan pada hari Jum'at, tanggal 2 Februari 2018, bertempat di Aula SMK Islam Kedungjati. Kegiatan dilaksanakan selama 50 menit dari jam 08.30 - 09.20 WIB untuk menyelesaikan 50 soal yang terdiri dari 15 soal listening dan 35 soal reading. Kegiatan ini diikuti oleh 66 siswa kelas XII yang terdiri siswa-siswa TKR (teknik Kendaraan Ringan), BB (Busana Butik) dan TAV (Teknik Audio Visual). Pelaksanaan pre-test di SMK Islam Sudirman Kedungjati terlihat dalam Gambar 4.

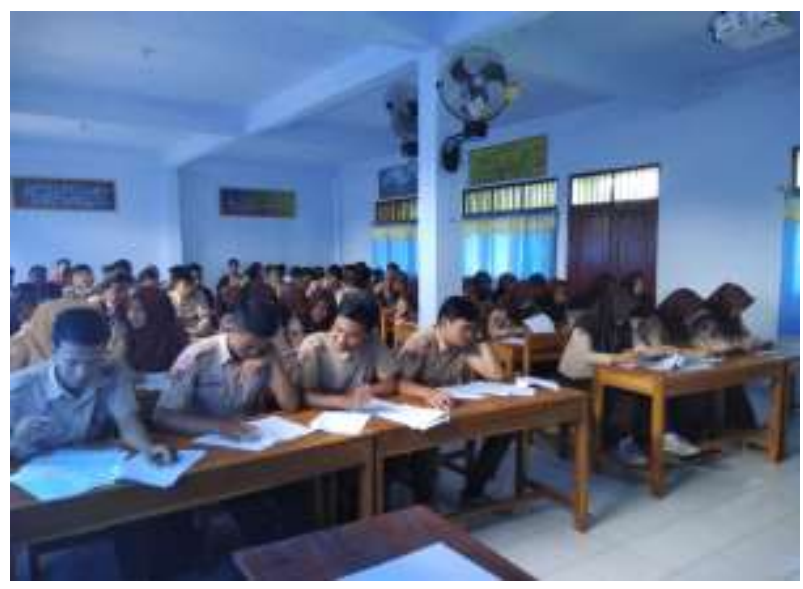

Gambar 4. Suasana Pre-Test di SMK Islam Sudirman Kedungjati

Sementara itu, pelaksanaan pre-test di SMA Islam Sudirman Kedungjati dilaksanakan pada hari Senin, 5 Februari 2018 bertempat di Perpustakaan SMA Islam Sudirman yang diikuti oleh 33 siswa kelas XII SMA Islam Sudirman yang terdiri dari kelas IPA dan IPS. Kegiatan ini berlangsung selama 50 menit dari jam 08.30 - 09.20 dengan menyelesaikan 50 butir soal yang terdiri dari 15 soal listening dan 35 soal reading. Kegiatan pre-test di SMA Islam Sudirman Kedungjati seperti tampak pada Gambar 5.

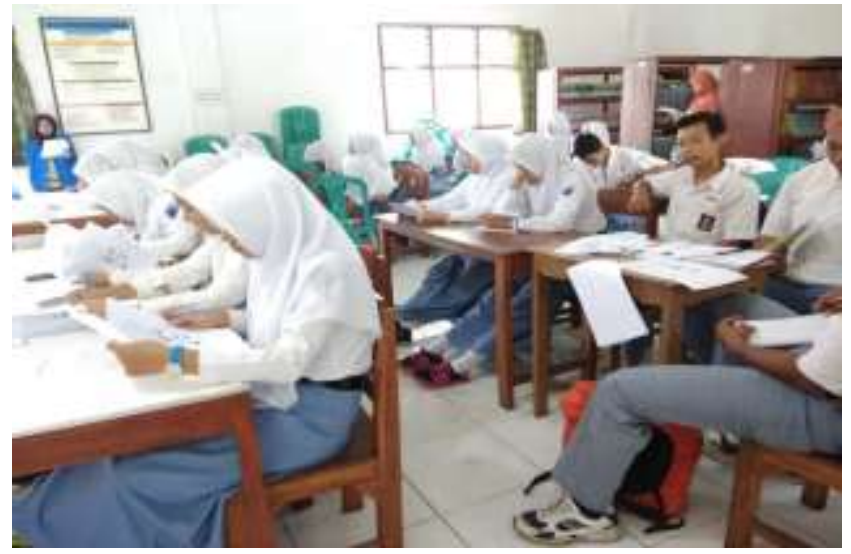

Gambar 5. Suasana Pre-Test di SMA Islam Sudirman Kedungjati

\section{Pembahasan Soal dan Penyampaian Tips dan Trik Pengerjaan Soal-Soal UN}


Setelah Pre-test selesai, kegiatan selanjutnya adalah pembahasa soal-soal UN. Pembahasan soalsoal ini dimaksudkan supaya siswa dapat mengenali tipe-tipe soal-soal Ujian Nasional maupun mengetahui tip dan trik mengerjakan soal sesuai dengan tipe soal.

\section{A. Tahap I: Mengenal Tipe-Tipe Soal}

Baik soal untuk SMA maupun SMK terdiri dari 2 jenis soal yaitu listening dan reading. Namun begitu, untuk soal SMA terdiri dari multiple choice atau pilihan ganda dengan 5 pilihan (A, B, C, D dan E). Sementara untuk soal SMK terdiri dari multiple choice dengan 4 pilihan (A, B, C dan D).

\section{1) Soal UN SMK}

\section{a. Listening}

Terdiri atas 4 jenis soal:
(1) Pictures
(2) Question-responses
(3) Short Conversation
(4) Short talks

b. Reading

Terdiri dari structure (mencari susuan yang salah) dan menjawab pertanyaan berdasar pada teks (reading comprehension and vocabularies)

\section{2) Soal UN SMA}

\section{a. Listening}

Terdiri atas 4 jenis soal:

(1) Short conversation

(2) Dialogue

(3) Monologue

\section{b. Reading}

(4) Pictures

Terdiri dari teks dan grammar in context.

\section{B. Tahap II: Strategi Penyelesaian Soal}

Dalam pembahasan soal sekaligus disampaikan strategi penyelesaian soal sesuai dengan tipe soal. Tip dan Trik penyelesaian soal adalah sebagai berikut:

1) Untuk soal listening berupa pictures, dicari clue word (kata kunci) untuk setiap soal.

2) Untuk soal listening yang berupa dialogue perhatikan dengan seksama pihak-pihak yang sedang berdialog dan isinya.

3) Untuk soal reading, bacalah soal terlebih dahulu baru membaca teksnya untuk menghemat waktu.

4) Untuk mencari padan kata attau sinonim dapat dilaukan dengan guessing caranya baca satu kalimat secara utuh dan perkirakan arti katanya.

5) Untuk soal yang berupa grammar, tidak perlu mengetahui arti seluruh kata dalam kalimat. Yang perlu dipahami adalah ketentuan atau kaidah tata Bahasa Inggris dan tensesnya. 6 dan 7

Kegiatan penyampaian tip dan trik pengerjaan soal UN SMK dan SMA dapat dilihat pada Gambar

\section{Post-Test}

Setelah pemberian treatment, kegiatan dilanjutkan dengan post-test untuk mengetahui perubahan dan perbedaan sebelum dan setelah dilakukan treatment. Post-test dilakukan pada kedua mitra dengan menggunakan soal yang sama pada waktu pre-test. Dari hasil pre-test dan post-test kemuadian akan dibandingkan untuk melihat perubahan yang signifikan.

Post-test pada kedua mitra dilaksanakan pada hari yang sama pada saat pre-test. Di SMK Islam Sudirman Kedungjati dilaksanakan pada hari Jum'at, tanggal 2 Februari 2018 dan di SMA Islam Sudirman dilaksanakan pada hari Senin, 5 Februari 2018 bertempat di masing-masing sekolah. Hasil dari pre-test dan post test dapat dilihat pada lampiran. 


\section{Buletin Pembangunan Berkelanjutan}

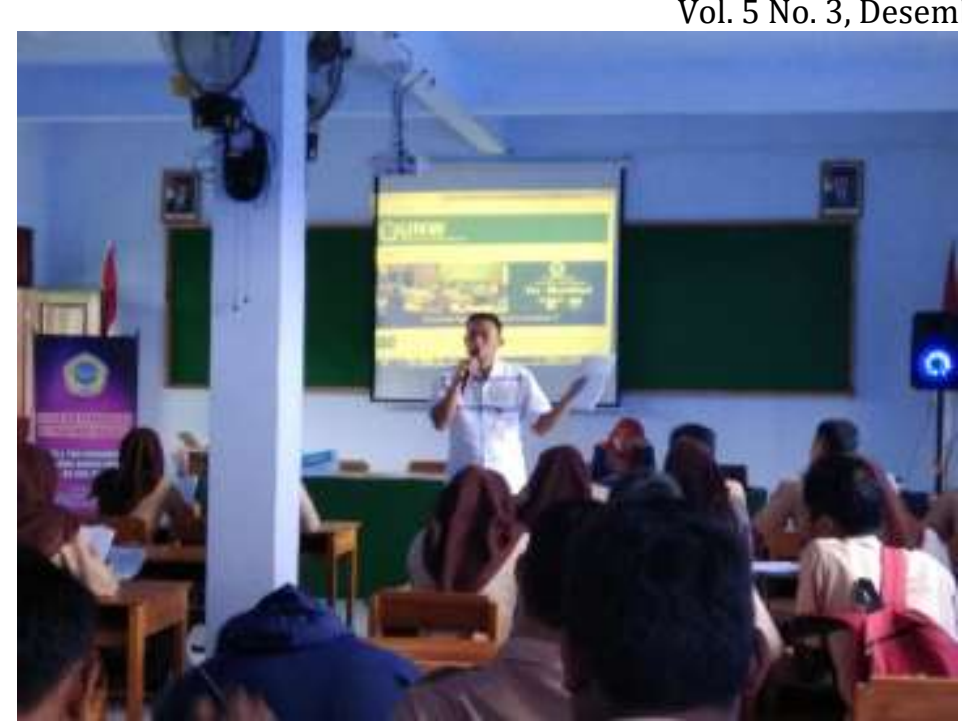

Gambar 6. Suasana Penyampaian Tips dan Trik Soal-Soal UN di SMK Islam Sudirman Kedungjati

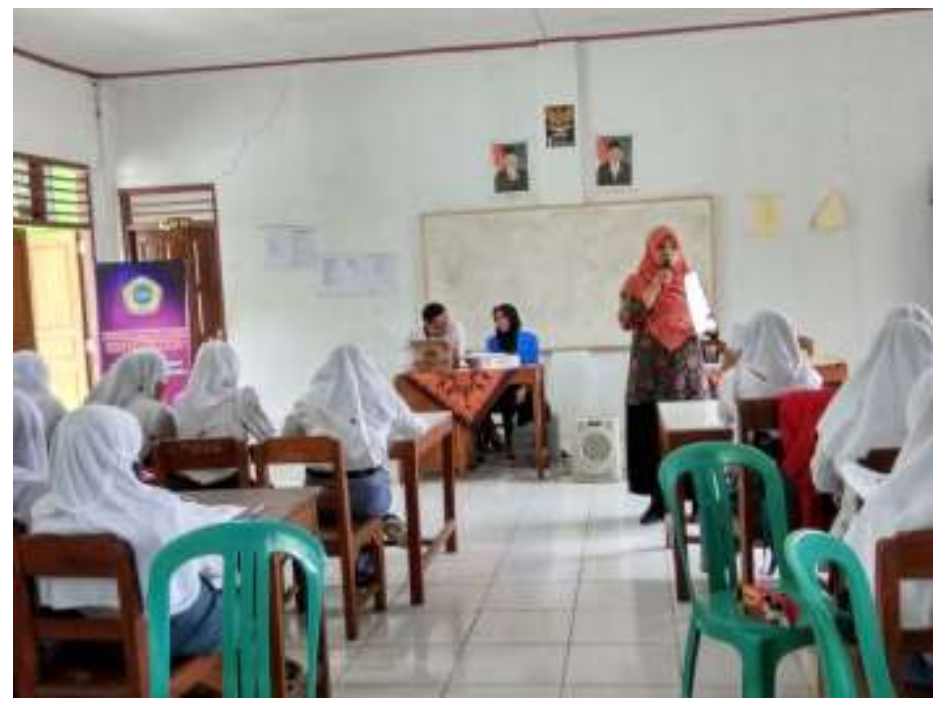

Gambar 7. Suasana Penyampaian Tips dan Trik Soal-Soal UN di SMA Islam Sudirman Kedungjati

\section{Evaluasi}

Tahap selanjutnya dari kegiatan ini adalah evaluasi. Evaluasi ini dilakukan dengan membandingkan hasil dari pre-test dan post-test dari masing-masing mitra. Hasil pre-test dan post-test di SMK Islam Sudirman dapat disimpulkan sebagai berikut; 1) rata-rata nilai pre-test adalah 30.64, 2) rata-rata nilai post-test adalah 40.39 , 3) Kenaikan rata-rata nilai pre-test ke post-test adalah 9.76 atau $38.99 \%$. Nilai tertinggi pada saat pre-test adalah 60 diraih oleh M. Naviul Iroba dan nilai post-test tertinggi adalah 64 diraih oleh siswa yang sama. Nilai terendah pada saat pre-test adalah 12 dan nilai terendah post test adalah 18 . Hasil secara detail terlampir.

Sementara itu, hasil pre-test dan post test di SMA Islam Sudirman dapat disimpulkan sebagai berikut; 1) rata-rata nilai pre-test adalah 26.73 , 2) rata-rata nilai post-test adalah $30.06,3$ ) Kenaikan rata-rata nilai pre-test ke post-test adalah 3.33 atau 14.03\%. Nilai tertinggi pada saat pre-test adalah 46 diraih oleh Yuni Mundadhiroh dan nilai post-test tertinggi adalah 44 diraih oleh Riska Ayu. Nilai terendah pada saat pre-test adalah 14 dan nilai terendah post test adalah 24 . Hasil secara detail terlampir.

Dari membandingkan nilai rata-rata pre-test dan post-test pada kedua mitra, dapat disimpulkan bahwa ada perubahan yang signifikan pada hasil simulasi soal-soal UN. Hal ini berarti ada nilai kebermanfaatan dari kegiatan pengabdian masyarakat pada kedua mitra. 


\section{KESIMPULAN}

Dari pelaksanaan kegiatan pengabdian masyarakat yang telah dilaksanakan berupa pemberian tips dan trik pengerjaan soal-soal Ujian Nasional SMA dan SMK di SMA dan SMK Islam Sudirman Kedungjati, Grobogan dapat disimpulkan sebagai berikut:

1. Program pengabdian masyarakat ini sebagai bentuk kegiatan Tri Dharma Perguruan Tinggi Universitas Ngudi Waluyo dalam rangka memberikan manfaat bagi masyarakat sekitar, dalam hal ini adalah sekolah mitra guna meningkatkan kemampuan siswa dalam menghadapi Ujian Nasional dengan memberikan tips dan trik pengerjaan soal-soal Bahasa Inggris UN melalui simulasi dan pembahasan soal-soal UN.

2. Kegiatan ini memberikan pengetahuan dan wawasan kepada sekolah mitra dalam rangka meningkatkan angka partisipasi belajar di perguruan tinggi dengan memperkenalkan keberadaan Universitas Ngudi Waluyo kepada masyarakat di kedua sekolah mitra maupun masyarakat Kedungjati, Grobogan pada umumnya.

3. Kegiatan pengabdian masyarakat di sekolah-sekolah mitra ini memberikan manfaat bagi para siswa kelas XII dalam rangka menghadapi Ujian Nasional. Kegiatan ini memberikan pengetahuan dan kesempatan yang lebih untuk berlatih menghadapi Ujian Nasional SMA/SMK melalui simulasi.

4. Dari kegiatan ini dapat dilihat kemampuan dasar dan persiapan para siswa di sekolah mitra dalam menghadapi Ujian Nasional SMA/SMK, sehingga diharapkan para siswa lebih mempersiapkan dirinya.

Dengan kegiatan ini diharapkan mampu memberikan gambaran umum mengenai kesiapan para siswa dalam menghadapi Ujian Nasional SMA/SMK sehingga para guru dan pihak-pihak yang terlibat mampu mengambil kebijakan untuk lebih mempersiapkan para siswanya dalam menghadapi Ujian Nasional SMA/SMK. Dan juga siswa diharapkan mampu mengambil manfaat dari kegiatan ini dengan menggunakan tips dan trik yang telah diberikan untuk mengerjakan soal-soal Bahasa Inggris UN.

Diharapkan ada kegiatan-kegiatan yang serupa untuk mata pelajaran yang lain, sehingga siswasiswa terutama yang tinggal di daerah mempunyai kesempatan yang lebih untuk berlatih mengerjakan soal-soal Ujian Nasional.

Memuat makna hasil kegiatan dan jawaban atas tujuan kegiatan serta saran atau rekomendasi kebijakan untuk keberlanjutan program. Kesimpulan dapat berupa paragraf, namun sebaiknya berbentuk point-point dengan menggunakan numbering.

\section{DAFTAR PUSTAKA}

Alawiyah, Faridah .2015. Perubahan Kebijakan Ujian Nasional. Aspirasi Vol. 6 No. 2, Desember 2015

Hidayah, Nurul. 2013.Ujian Nasional Dalam Perspektif Kebijakan Publik. Jurnal Pencerahan Volume 7, Nomor 1, (Maret) 2013 Halaman 35-40

Kebijakan Ujian Nasional Tahun 2018. https://www.sudutbaca.com/kebijakan-ujian-nasionaltahun-2018/

Kisi-kisi Ujian Nasional SMA/SMK. https://www.kemdikbud.go.id

Profil SMK Islam Sudirman Kedungjati. http://20313800.siap-sekolah.com/sekolahprofil/sekolah-daftarprasarana/ 